\title{
Beyond Neoclassical Economics: The Impact of Religion on the Economic Disparity between Georgia and Estonia
}

\author{
Anastasia Mgaloblishvili \\ Department of Law, \\ School of Business and Governance, \\ Tallinn University of Technology \\ Akadeemia tee 3 , \\ Tallinn 12618, Estonia \\ E-mail: a.mgaloblishvili@outlook.com
}

\begin{abstract}
The aim of this article is to examine the impact religion has had on the post-Soviet economic development of Georgia and Estonia. The role of religion in economic development has been neglected in the field of social sciences, in which political and economic theories dominate. Considering the difference in the religiosity of the two countries-Georgia is one of the most religious countries in Europe while Estonia is the most atheist-religion will be incorporated as a factor that could have directly or indirectly impacted the post-Soviet development of the two countries. By studying the relationship of the church and the state in the two countries and the population's economic attitudes that may have been influenced by their religiosity, this paper will conclude that religion can be considered a contributing factor in the economic divergence between Estonia and Georgia. The article's overall findings will suggest that the practice of Eastern Orthodoxy in Georgia impedes the development of good governance and a free market economy, whereas the opposite holds for Protestantism or atheism in Estonia.
\end{abstract}

Keywords: economic development, Estonia, Georgia, religion 


\section{Introduction}

Twenty-six years after gaining independence from the Soviet Union (USSR), the difference in the economic well-being of Estonia and Georgia remains substantial, with Estonia having a per capita GDP three times the size of Georgia's (The World Bank, 2018). In political economy, the disparity between the two countries is explained by the dominant neoclassical theory, which emphasizes the significance of good governance, free markets, and trade liberalization in stimulating economic development (Kerikmäe et al., 2014). Nevertheless, limited attention is given to the effect that culture and specifically religion may have on shaping the abovementioned factors. Of the former Soviet republics, however, Georgia and Estonia stand on the opposite ends of the spectrum when it comes to their religiosity. Whereas Georgia is one of the most religious countries of the post-Soviet republics with a dominantly Eastern Orthodox population, Estonia is the most atheist, with a combination of Eastern Orthodox and Protestant denominations. Considering this difference, this article will study religion as an independent variable that could have affected the development of neoclassical growth factors - the dependent variables - in Georgia and Estonia. It will find the level of religiosity in Georgia to have impeded the development of good governance and a free market economy, whereas the opposite to have been the case in Estonia.

The relationship between religion and economic development was first studied by the economic sociologist Max Weber, who introduced the term "economic ethic" and defined it as "practical impulses for action which are founded in the psychological and pragmatic contexts of religions" (Weber et al., 1982[1948], pp. 267-290). Weber argued Protestantism to be the religious denomination that most effectively shapes one's economic ethic since its theological foundation prompts its adherents to serve God and seek salvation not through the contemplative manner characterizing Eastern religions of Hinduism and Confucianism, i.e. detaching oneself from the world and seeking God in that sense (Weber et al., 1982 [1948], pp. 267-290), nor through the religious doctrinal manner characteristic of Catholic and Orthodox Christianity, i.e. serving God merely through religious activities (Bulgakov, 1909), but through a persistent, secular work-ethic. Similarly, the political scientist Samuel Huntington has also differentiated between Eastern and Western Christianity, claiming that whereas in Western Christianity "God and Caesar" - the church and stateexist independently from each other, in Eastern Orthodoxy "God is Caesar's junior partner" (Huntington, 1996). Despite the writings of these scholars, the secularization theory that contemporary political science is built on has assumed 
religion to have been privatized and hence no longer a concern of the public state, and consequently their works are rarely consulted in contemporary development studies. Instead, neoclassical economics with its emphasis on good governance and free markets dominates contemporary development economics.

Through the case studies of Georgia and Estonia, this article will study how religion could have impacted the factors neoclassical economics deems as necessary for successful economic development-specifically, good governance. The first section will begin by examining the historiography of the two countries before and during the Soviet Union to explain the different place for religion in Georgia and Estonia today. Whereas in Estonia Western Christianity was used to integrate the country to Western Europe, in Georgia Eastern Christianity was the country's method of self-preservation from foreign rule and hence could be said to have bred ethnic nationalism in the country. The second section will study the church and state relationships in the two countries and how they impact the level of good governance in the respective country. In Georgia, the Eastern Orthodox Church is the most trusted institution in the country (Gurchiani, 2017) and hence the Georgian leadership has been profoundly restricted by and tied to the institution. On the other hand, in Estonia the churches and religious organizations are merely minorities of the population, and hence their role in politics has also remained minimal (Ringvee, 2001). The third section will analyse the data from the World Value Survey (WVS) to study how certain values conducive to economic growth may be affected by the population's religiosity. The methodology for this research will primarily be based on the discourse analysis of Georgia and Estonia's historiography, contemporary development theories, and findings of religious scholars. The WVS data analysis will be conducted through the website's online data analysis tool.

\section{Religion and its place in the history of Georgia and Estonia}

When studying Georgia's post-Soviet economic development, development scholar Anders Åslund (2012, p. 26) identifies the country's "ancient minorities, national disputes, and political violence" as the main constraints to its economic development. These constraints, accordingly, can be traced back to Georgia's historic past before and during the Soviet rule. Although it had its short-lived independence in 1918-1921, Georgia throughout history existed as a fragmented territory (Wheatley, 2009) mostly under Ottoman, Persian, or Russian rule. As the only Christian country under the former two powers, Christianity became a 
defining feature of its national identity (Chikovani, 2012) and hence a form of self-preservation under a cultural threat. The historiography of the country since the early medieval ages has been characterized as the "struggles of Christian kings against Muslim invasions" (Javakhishvili et al., 1943; Javakhishvili, 1960 in Gurchiani, 2017). People of non-Orthodox religion were considered as "French" if they were Catholic Georgians and "Tatars" if they were Muslim Georgians (Gurchiani, 2017). Consequently, Georgia's self-identification as one of the first Christian nations, together with its unique language and culture, paved way to, as Chikovani (2012) puts it, the "notion of ethnic exceptionalism" to develop among the population. In turn, ethnic nationalism in Georgia left an ambiguous place for and created tensions with Georgia's ethnic minorities, which only intensified following the Soviet occupation of the country.

Although during the Soviet rule there was an attempt to diminish such national sentiments in the hope of creating a common Soviet identity (Chikovani, 2012), it may have had a reverse effect in Soviet Georgia—nationalism nevertheless prevailed, and USSR's ethno-federalist division served as the foundation for Georgia's post-independence inter-ethnic tensions (Wheatley, 2009; Chikovani, 2012). The Soviet Union was divided territorially into a hierarchical system mostly based on the nationality of the residing population, and consequently two autonomous republics - Abkhazia and Adjara - and one autonomous oblastSouth Ossetia - were carved out within Georgia (Wheatley, 2009). Abkhazia and South Ossetia due the population's "distinct nationalities," and Adjara due to its large Muslim population. A combination of strong national sentiments, the USSR's fragmentation of Georgia on an ethnic basis, and Russia's strategic interests in the country resulted in three wars to break out in Georgia postindependence - in South Ossetia in 1991, in Abkhazia in 1992, and again in South Ossetia in 2008 (Chochia \& Popjanevski, 2016). By the end of 1992, Georgia's GDP had fallen by $44.2 \%$ (Wheatley, 2009), by the end of 2008, by $3.65 \%$ (The World Bank, 2018). Figure 1 displays the GDP growth rate of the two countries from the earliest data available after their independence.

As Figure 1 shows, Georgia's GDP growth decreased immensely in 1992 and substantially again in 2009 - coinciding with the years following the two wars in the country. Hence, Georgia's barriers to economic development can be partly attributed to its historical background that gradually created and strengthened a strong sense of ethnic identity among the Georgian population. Aside from direct economic effects, ethnic nationalism in Georgia has also had indirect outcomes on Georgia's economic development as it impeded the development of good governance indices in the country (Hoffmann \& Chochia, 2018). For instance, one dimension of governance measured by the World Bank's 
Figure 1. GDP growth in Georgia and Estonia 1990-2016, annual \%

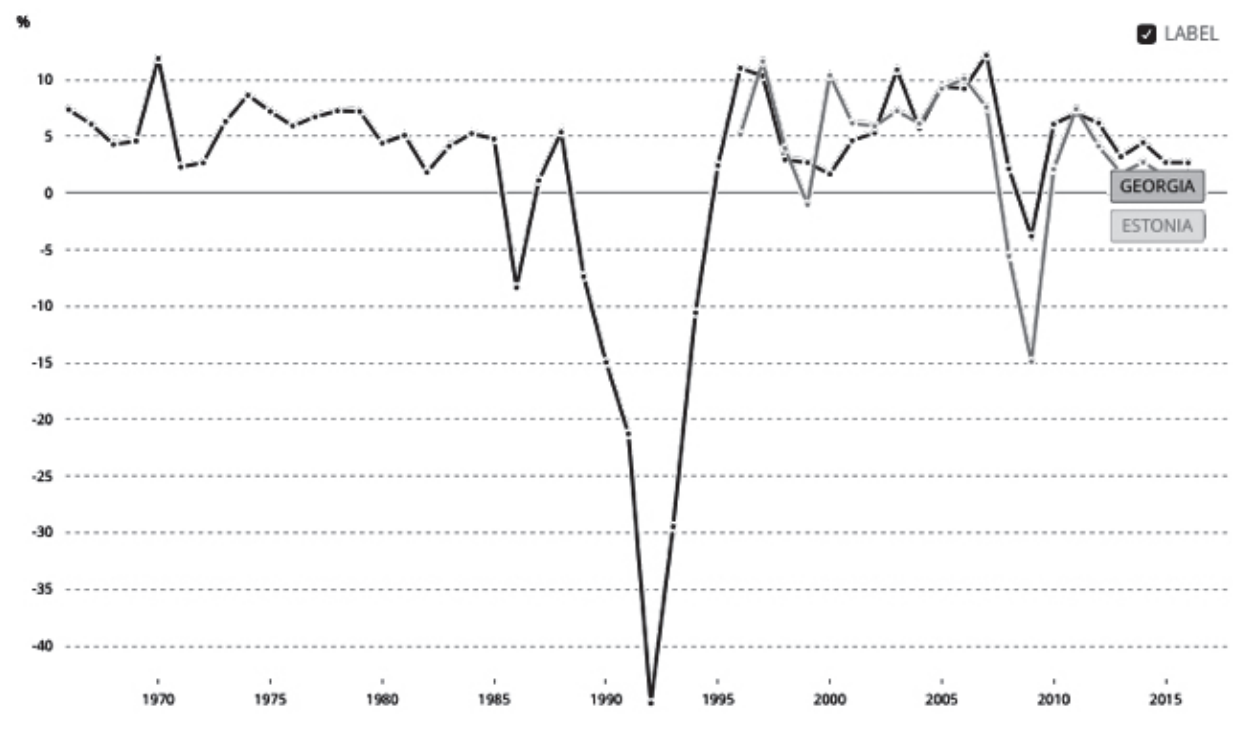

Source: The World Bank, 2018

Worldwide Governance Indicators-voice and accountability-measures the "extent to which a country's citizens are able to participate in selecting their government, as well as freedom of expression, freedom of association, and a free media" (The World Bank, 2018). Georgia's history and policies that prioritize "ethnic" Georgians over ethnic minorities impede the development of the inclusive society necessary for the development of good governance. As Table 1 shows, Estonia is substantially ahead of Georgia in the World Bank's six good governance indicators - voice and accountability, political stability and absence of violence/terrorism, government effectiveness, regulatory quality, rule of law, and control of corruption.

When it comes to post-Soviet Estonia, Åslund (2012, p. 32) cites Lieven (1993) that it was "ripe for full democracy and radical economic reform. [Its] national objectives were firmly set: to turn their back on Russia, to reintegrate with the West, and to establish ordinary Western [...] systems." The reason why Estonia was "ripe for full democracy and economic reform" while Georgia was not can be explained by the German and Swedish domination of the country, which resulted in the qualities "unique" to the West (Huntington, 1996) to also become imbedded in the Estonian identity - Western Christianity, rationalism, Roman law. Consequently, when Estonia was later under the Russian and the Soviet rule, it did not succumb to its influence and, as the Estonian historian Made (2003) writes, 
Beyond Neoclassical Economics: The Impact of Religion on the Economic Disparity between Georgia and Estonia

Table 1. The World Bank's good governance indicators

\begin{tabular}{|c|c|c|c|}
\hline Indicator & Country & Year & $\begin{array}{l}\text { Percentile Rank } \\
\text { (0 to 100) }\end{array}$ \\
\hline \multirow[t]{6}{*}{ Voice and Accountability } & \multirow[t]{3}{*}{ Estonis } & 2006 & \\
\hline & & 2011 & \\
\hline & & 2016 & \\
\hline & \multirow[t]{3}{*}{ Georgia } & 2006 & - \\
\hline & & 2011 & $=$ \\
\hline & & 2016 & - \\
\hline \multirow{6}{*}{$\begin{array}{l}\text { Political Stability and } \\
\text { Absence of } \\
\text { Violence/Terrorism }\end{array}$} & \multirow[t]{3}{*}{ Estonia } & 2006 & $=$ \\
\hline & & 2011 & \\
\hline & & 2016 & \\
\hline & \multirow[t]{3}{*}{ Georgia } & 2006 & \\
\hline & & 2011 & - \\
\hline & & 2016 & \\
\hline \multirow[t]{6}{*}{ Government Effectiveness } & \multirow[t]{3}{*}{ Estonis } & 2006 & \\
\hline & & 2011 & \\
\hline & & 2016 & \\
\hline & \multirow[t]{3}{*}{ Georgis } & 2006 & \\
\hline & & 2011 & \\
\hline & & 2016 & \\
\hline \multirow[t]{6}{*}{ Regulatory Quality } & \multirow[t]{3}{*}{ Estonis } & 2006 & \\
\hline & & 2011 & \\
\hline & & 2016 & \\
\hline & \multirow[t]{3}{*}{ Georgis } & 2006 & $\longrightarrow$ \\
\hline & & 2011 & \\
\hline & & 2016 & \\
\hline \multirow[t]{6}{*}{ Rule of law } & \multirow[t]{3}{*}{ Estonis } & 2006 & \\
\hline & & 2011 & \\
\hline & & 2016 & \\
\hline & \multirow[t]{3}{*}{ Georgis } & 2006 & - \\
\hline & & 2011 & - \\
\hline & & 2016 & $\longrightarrow$ \\
\hline \multirow[t]{6}{*}{ Control of Corruption } & \multirow[t]{3}{*}{ Estonis } & 2006 & \\
\hline & & 2011 & \\
\hline & & 2016 & \\
\hline & \multirow[t]{3}{*}{ Georgis } & 2006 & 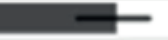 \\
\hline & & 2011 & \\
\hline & & 2016 & \\
\hline
\end{tabular}


was portrayed as a part of the Western civilization during the restoration period starting in the 1980 s.

Although referred to as "700 years of slavery" (Made, 2003) before the 1940s, the contemporary perspective of Estonian history recognizes that the German conquest of the country from the thirteenth to the early twentieth century resulted in culturally linking Estonia to Europe-Western Christianity was established in the Estonian territory in the thirteenth century (Made, 2003), and the Protestant Reformation led to the establishment of Protestantism as the dominant religious denomination in the country (Ringvee, 2001). The German legacy was not merely cultural-its institutions served as a blueprint for Estonia's developing public sector from the late nineteenth century onwards, where the German legal system was especially influential. Furthermore, industrialization, urbanization, and technical modernization led to the development of "modern European political trends such as socialism and liberal democracy to the Baltic provinces." (Made, 2003) Similarly, the Swedish conquest of the seventeenth century is referred to by Estonian historian Reiman (in Kuldkepp, 2013) as "a dawn before the real time of the dawn." As he writes, the Swedish rule resulted in the "the seeds of freedom and civilization" to be planted in the country that begun "to flourish when the time of the dawn (Estonian independence) began to arrive."

The difference in Estonia's and Georgia's pre-Soviet past can be considered as one of the factors why the Soviet influence was more difficult to overcome in Georgia. Although both countries turned to nationalism for self-preservation from the hardships of the Soviet domination, instead of turning to its "ethnic exceptionalism" like Georgia did, Estonia's nationalism consisted of "identifying itself as a part of the wider group of nations in order to complete its cultural identity and to ensure freedom" (Kuldkepp, 2013). Pigenko and Novac (2002) provide an explanation for this by stating that the role nationalism had on different societies cannot be generalized and can be "understood only when it is recognized as a part of the articulation of social formations." Hence, instead of turning to its "unique" ethnicity like Georgia did, Estonia turned to Finland, Scandinavia, and Europe (Pigenko \& Novac, 2002). 


\section{Secular in theory, secular in practice? Church and state ties in Georgia and Estonia}

Considering the significance of religion in the history and self-identity of Georgia, the Georgian Orthodox Church as a religious institution has had a prominent role in shaping the country's politics and economic development. Although religion remained crucial in Georgia despite the Marxist-atheist ideology of the Soviet rule, the Georgian Orthodox Church itself gained its power and legitimacy post-independence during Eduard Shevardnadze's rule in the 1990s (Batiashvili in Sutidze, 2015). As Batiashvili puts it, this was the period when the "secularization" of the church occurred - the church refused to become the national religion of Georgia, but nevertheless, due to the weakness of state institutions during Shevardnadze's time, begun to exercise profound informal power over the Georgian citizens by offering them the basic security that they lacked from the state. The church built its legitimacy by combining Georgia's national identity with religion and implying in its behavior, as Georgian religious expert Levan Sutidze (2015) puts it, that the "Georgian identity exists because of me" or "If you do not ask for my opinion, you are going against the Georgian nation." Although as a result of the Concordat of 2002 the church had no formal power (Sutidze, 2015), everything that has cultural legitimacy has to this day remained in the hands of the Georgian Orthodox Church (Batiashvili in Sutidze, 2015). The informal power possessed by the Orthodox Church can be partly attributed to the theological foundation of Eastern Orthodoxy, which, as Gurchiani (2017) writes, is managed through an ecclesiastical economy. In comparison to divine and akribia economy, ecclesiastical economy gives the church the power to handle certain rules and practices that, in the case of the former two, would be determined either through the letter of the law or teachings of God (Gurchiani, 2017).

Consequently, although the 1995 Constitution of Georgia declared the freedom of religion and the independence and separation of the Georgian Orthodox Church from the state, it nevertheless emphasized the "special role of the Orthodox Church in history of Georgia" (Grdzelidze, 2010). The "special role" given to the Orthodox Church has been conspicuous throughout the rule of Mikheil Saakashvili, who continued to provide government funding to the Georgian Orthodox Church with the premise of compensating it for the damage done under the rule of the Russian Empire and the Soviet Union. Furthermore, the church became free of the revenue tax and taxes related to its production, non-commercial property, and land. (Grdzelidze, 2010) In 2013, Transparency International estimated that the Georgian Orthodox Church received 200 million 
Georgian lari-approximately 125 million US dollars-of funding (Metreveli, 2016) throughout the past twelve years. Saakashvili's regime also increased the funding to the church since November 2007, which was the period when his regime faced both internal and external criticism for the crackdown of opposition protests in the country (Gredzildze, 2010). The amount of state funding allocated to the Patriarchate from 2002-2013 can be seen in Figure 2 below, with a clear increase from 2007 onwards.

Figure 2. State budget funding allocated to the Georgian Patriarchate in 2002-2013, GEL million

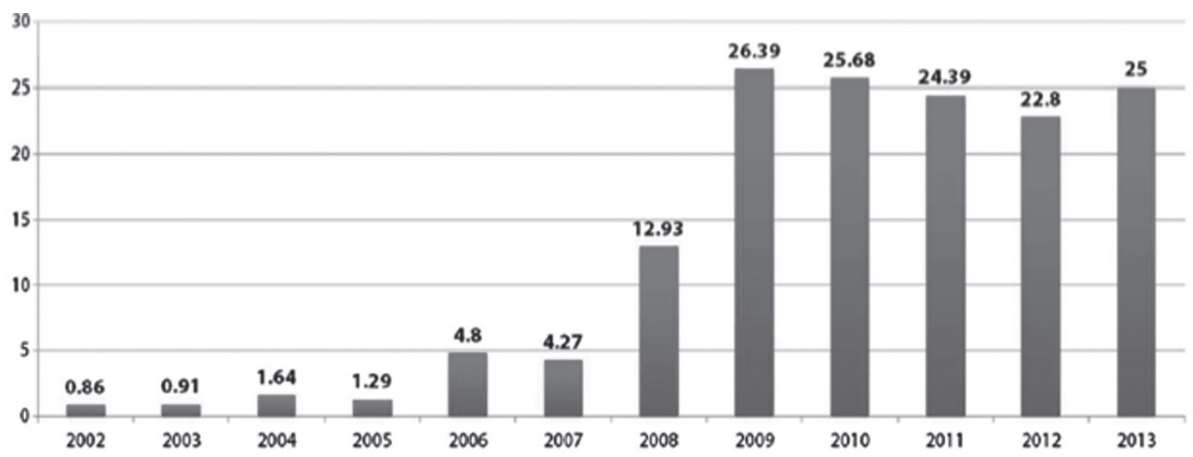

Source: Metreveli, 2016

In turn, the significant position of the Orthodox Church in Georgia's politics can be considered both a direct and an indirect hindrance to Georgia's economic development - direct because the substantial portion of the government revenue given to the church could instead have been spent on factors that could hasten Georgia's economic development, and indirect because the church has revealed tendencies and characteristics that counteract factors conducive to economic development. For example, the Georgian Orthodox Church has called for the re-establishment of a monarchy in Georgia (Grdzelidze, 2010), which would subsequently strengthen the ethnic nationalistic sentiments in the state and impede democratization. Furthermore, Sutidze (2015) states that although the Patriarchate of Georgia theoretically supports Georgia's development and Westernization, its actions have proven otherwise. For instance, during a visit to Adjara, a Georgian region with a significantly large Muslim population, the Patriarch assured the citizens of the region that they "too" are Georgians. The Georgian expression of "you too", tkvents, he used, however, leaves a connotation that the population are still partly, rather than fully, Georgians. 
Considering the minimal role religion has in the public life of Estonia, the role of the religious institutions in the country's politics has also remained minimal. Although the Estonian Evangelical Lutheran Church and the Russian Orthodox Church can be considered the largest religious associations in the country (Ringvee, 2001), they make up such a minor portion of the Estonian society that their impact on politics has been insignificant. Respectively, the state has given no preference to any association - the country's constitution emphasizes the freedom of consciousness and religion and declares that there is no state church (Kerikmäe, 2009). Additionally, the Law on Churches and Congregations "places all religious communities on equal ground," and gives each person-Estonian citizen or not - the right to establish its own religious community, which has to have at least twelve remembers and must be registered in the Estonian government (Ringvee, 2001). According to Ringo Ringvee, the relationship between the church and state in Estonia has been built on the mutual trust between the two parties, and on the notion of "less control, more trust." Ringvee states that the religious communities constitute too insignificant of a place in the Estonian society to make requests for special treatment that will be accepted by the society at large (Ringvee, 2001). Today, Estonia is one of the most atheist countries in Europe, if not in the world. According to the WVS data from 2011, only $25.3 \%$ of the country's population considered religion from "rather" to "very" important in their daily lives. Of the population, $64.1 \%$ do not belong to any religious denomination, while $7.6 \%$ are Protestant and $23 \%$ are Orthodox (World Value Survey, 2018). For historical reasons, however, the Estonian Evangelical Lutheran Church has maintained a leading role as a religious institution until the early twenty-first century (Ringvee, 2001). Consequently, whereas the place of the Orthodox Church in Georgia can be considered as an impediment to Georgia's economic development, the religious institutions in Estonia seem to have no defining role in the country's politics and economics. The proceeding section will compare how the difference in the two countries' religiosity differently shapes their values conducive to economic growth. Additionally, it will compare the significance of the religious institutions in the two countries to the significance of government institutions according to the WVS data to better understand the reason behind different place of religion in the Georgian and Estonian societies. 


\section{The Impact of religion on the population's "economic ethic": interpreting the World Value Survey}

The WVS values chosen for a comparison are the ones that showed the greatest divergence between Georgia and Estonia - attitude towards science vs. religion, significance placed on tradition, and trust in religious vs. government institutions. Since these values are considered either directly or indirectly conducive to economic development, they were cross-tabulated with the populations' religiosity to determine whether religion can to an extent explain the divergence in the respective values.

Table 2. General religiosity of Georgia and Estonia

\begin{tabular}{|l|r|r|r|}
\hline & & \multicolumn{2}{|c|}{ Country Code } \\
\cline { 3 - 4 } & TOTAL & Estonia & Georgia \\
\hline A religious person & $60.0 \%$ & $30.9 \%$ & $97.1 \%$ \\
\hline Not a religious person & $32.4 \%$ & $55.9 \%$ & $2.5 \%$ \\
\hline An atheist & $4.3 \%$ & $7.4 \%$ & $0.2 \%$ \\
\hline No answer & $0.3 \%$ & $0.5 \%$ & - \\
\hline Don't know & $3.0 \%$ & $5.3 \%$ & $0.2 \%$ \\
\hline (N) & $(2,735)$ & $(1,533)$ & $(1,202)$ \\
\hline Selected samples: Estonia 2011, Georgia 2014 & & & \\
\hline
\end{tabular}

Source: WVS, 2018

To begin with, the general religiosity of Georgia and Estonia is laid out in Table 2 above. As is evident from the figures, the difference between Georgia and Estonia's religiosity is substantial and can partly be explained by the contrasting impact of religion in shaping the two countries' history discussed in the previous section. In addition to their religiosity, Georgian and Estonian societies also diverge in their attitudes towards science vs. religion, tradition, and trust in institutions. The proceeding sections will begin by measuring the difference in these variables and continue by cross-tabulating them with the countries' religiosity to determine whether they are correlated to each other.

\subsection{Attitudes towards tradition and science}

Science is a determining factor in the development of three factors identified by the neoclassical theory as essential for output growth: labor quality and/or quantity, capital, and technology (Todaro \& Smith, 2010, p. 128) and, hence, the difference in the attitudes of the two societies towards science and religion may 
partly explain the countries' divergence in economic development. The table below presents the responses to the following question: "Whenever science and religion conflict, religion is always right."

Table 3. Science vs. religion

\begin{tabular}{|l|r|r|r|}
\hline & & \multicolumn{2}{|c|}{ Country Code } \\
\cline { 3 - 4 } & TOTAL & Estonia & Georgia \\
\hline Strongly agree & $12.5 \%$ & $2.1 \%$ & $25.8 \%$ \\
\hline Agree & $19.5 \%$ & $9.0 \%$ & $32.9 \%$ \\
\hline Disagree & $31.2 \%$ & $36.5 \%$ & $24.5 \%$ \\
\hline Strongly disagree & $26.9 \%$ & $43.8 \%$ & $5.5 \%$ \\
\hline Don't know & $9.8 \%$ & $8.6 \%$ & $11.4 \%$ \\
\hline$(N)$ & $(2,735)$ & $(1,533)$ & $(1,202)$ \\
\hline
\end{tabular}

Source: WVS, 2018

While more than half of the Georgian respondents agree- "strongly agree" and "agree" - that religion is to be trusted more than science, merely $11.1 \%$ of Estonian respondents share the belief. The historical significance of religion in shaping Georgia's national identity may explain the reason behind the prioritization of religion over science in the Georgian society. On the other hand, Western Christianity in Estonia can to an extent be attributed to its scientific development, and hence the reverse argument holds true in Estonia. To test whether the dominance of religion over science can be attributed to the difference in Georgia and Estonia's religiosity, the tables below cross-tabulate the Georgian and Estonian populations' attitudes towards science/religion and their religiosity.

Table 4. Attitude towards science vs. religion when religiosity = "a religious person"

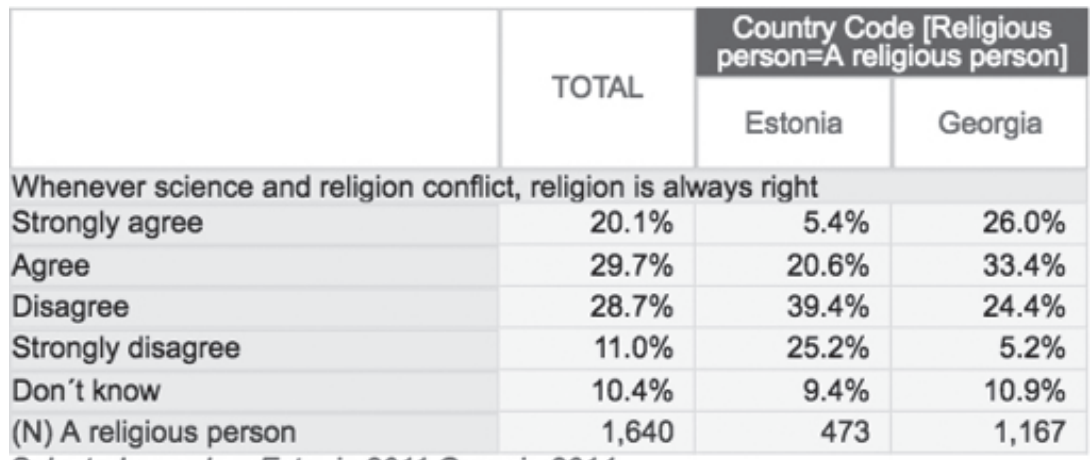

Selected samples: Estonia 2011, Georgia 2014

Source: WVS, 2018 
Table 5. Attitude towards science vs. religion when religiosity = "not a religious person"

\begin{tabular}{|c|c|c|c|}
\hline & \multirow{2}{*}{ TOTAL } & \multicolumn{2}{|c|}{$\begin{array}{c}\text { Country Code [Religious } \\
\text { person=Not a religious } \\
\text { person] }\end{array}$} \\
\hline & & Estonia & Georgia \\
\hline \multicolumn{4}{|c|}{ Whenever science and religion conflict, religion is always right } \\
\hline Strongly agree & $1.0 \%$ & $0.5 \%$ & $16.7 \%$ \\
\hline Agree & $4.5 \%$ & $4.2 \%$ & $13.3 \%$ \\
\hline Disagree & $37.7 \%$ & $38.0 \%$ & $30.0 \%$ \\
\hline Strongly disagree & $49.2 \%$ & $50.5 \%$ & $13.3 \%$ \\
\hline Don't know & $7.6 \%$ & $6.9 \%$ & $26.7 \%$ \\
\hline (N) Not a religious person & 887 & 857 & 30 \\
\hline
\end{tabular}

Selected samples: Estonia 2011, Georgia 2014

Source: WVS, 2018

Table 6. Attitude towards science vs. religion when religiosity = "an atheist"

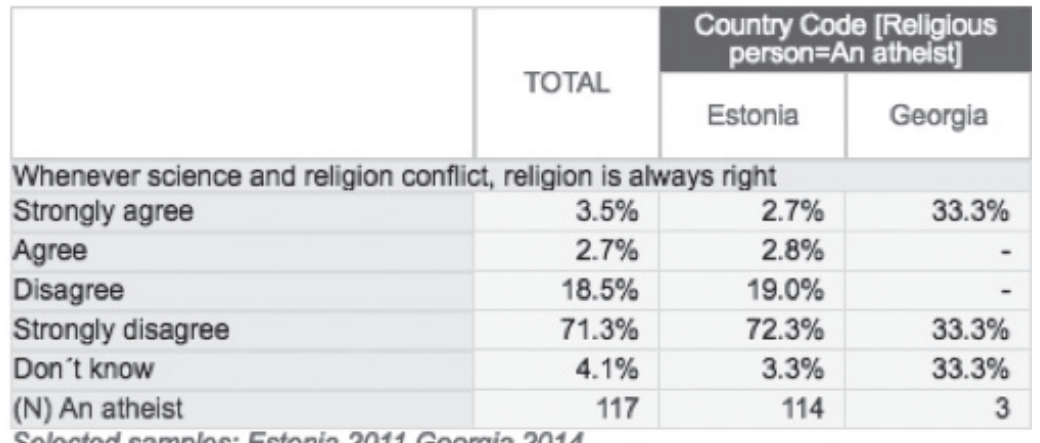

Selected samples: Estonia 2011, Georgia 2014

Source: WVS, 2018

As Tables 4-6 show, the respondents of both countries who identify themselves as religious place greater reliance on religion than do non-religious or atheist respondents. Nevertheless, the difference between religious Georgians and religious Estonians is substantial-with $60 \%$ of religious Georgians agreeing that "Whenever science and religion conflict, religion is always right," whereas $25 \%$ of the religious Estonians share the belief. Of the non-religious people, which in Estonia's case is the majority of the population, only $5.5 \%$ trust religion over science, and in Georgia the share reaches 30\%. The numbers are similarly low among the respondents who identify themselves as atheists. Consequently, it can be concluded that although, naturally, religious people in both countries show greater trust in religion vis-à-vis science than do non- 
religious or atheist respondents, the figures are nevertheless significantly higher in religious Georgians, implying that there may be something particular to Georgia's religiosity leading to these results.

Similar to the divergence in attitudes towards science, there is also a substantial gap between the significance the population of the two countries attach to tradition. Table 7 below displays the results to the following WVS question: "Tradition is important to this person; to follow the customs handed down by one's religion or family."

\section{Table 7. Significance of tradition in Georgia and Estonia}

\begin{tabular}{|l|r|r|r|}
\hline & & \multicolumn{2}{|c|}{ Country Code } \\
\cline { 3 - 4 } & TOTAL & Estonia & Georgia \\
\hline Very much like me & $32.8 \%$ & $14.4 \%$ & $56.2 \%$ \\
\hline Like me & $27.8 \%$ & $25.4 \%$ & $30.9 \%$ \\
\hline Somewhat like me & $18.8 \%$ & $27.1 \%$ & $8.2 \%$ \\
\hline A little like me & $11.4 \%$ & $18.6 \%$ & $2.3 \%$ \\
\hline Not like me & $5.6 \%$ & $9.1 \%$ & $1.2 \%$ \\
\hline Not at all like me & $2.0 \%$ & $3.3 \%$ & $0.2 \%$ \\
\hline Don't know & $1.6 \%$ & $2.0 \%$ & $1.0 \%$ \\
\hline (N) & $(2,735)$ & $(1,533)$ & $(1,202)$ \\
\hline
\end{tabular}

Source: WVS, 2018

As the figures above show, around $87 \%$ of the Georgian population finds tradition significant in their lives- "very much like me" and "like me"-, whereas merely $40 \%$ of the Estonian population share the belief. Orthodox Christianity's emphasis on tradition, religious symbolism, and religious faith (Tomka, 2011 in Metreveli, 2016) may explain the diverging attitude towards tradition in the two countries. To test whether a greater emphasis on tradition can be attributed to the difference in the two countries' religiosity, the question is again cross-tabulated with the two populations' religiosity.

As it was the case with the previous variable, significance placed on tradition is higher among the religious respondents of both Georgia and Estonia, yet the difference between the religious respondents of the two countries is still significant - with almost $88 \%$ of religious Georgians claiming tradition to be important, whereas only $55 \%$ of religious Estonians share the belief. The significance of tradition is nevertheless substantially high among the nonreligious respondents of Georgia, reaching up to $70 \%$, which proves that the significance one attaches to tradition does not merely have to do with their religiosity and may depend on other factors - such as the country's domestic conditions and/or historic legacies. 
Table 8. Significance of tradition when respondent = "a religious person"

\begin{tabular}{|l|r|r|r|}
\hline & TOTAL & \multicolumn{2}{|c|}{$\begin{array}{c}\text { Country Code [Religious } \\
\text { person=A religious person] }\end{array}$} \\
\cline { 3 - 4 } & & Estonia & Georgia \\
\hline $\begin{array}{l}\text { Schwartz: Tradition is important to this person; to follow the customs handed down } \\
\text { by one's religion or family }\end{array}$ & $47.8 \%$ & $25.7 \%$ & $56.7 \%$ \\
\hline $\begin{array}{l}\text { Very much like me } \\
\text { Like me }\end{array}$ & $30.5 \%$ & $29.3 \%$ & $30.9 \%$ \\
\hline Somewhat like me & $11.9 \%$ & $22.4 \%$ & $7.6 \%$ \\
\hline A little like me & $5.7 \%$ & $14.1 \%$ & $2.2 \%$ \\
\hline Not like me & $2.4 \%$ & $5.4 \%$ & $1.2 \%$ \\
\hline Not at all like me & $0.6 \%$ & $1.3 \%$ & $0.3 \%$ \\
\hline Don't know & $1.2 \%$ & $1.8 \%$ & $1.0 \%$ \\
\hline (N) A religious person & 1,640 & 473 & 1,167 \\
\hline
\end{tabular}

Source: WVS, 2018

Table 9. Significance of tradition when respondent = "not a religious person"

\begin{tabular}{|l|r|r|r|}
\hline & TOTAL & \multicolumn{3}{|c|}{$\begin{array}{c}\text { Country Code [Religious } \\
\text { person=Not a religious } \\
\text { person] }\end{array}$} \\
\cline { 3 - 5 } & & \multicolumn{1}{|c|}{ Estonia } & Georgia \\
\hline $\begin{array}{l}\text { Schwartz: Tradition is important to this person; to follow the customs handed down } \\
\text { by one's religion or family }\end{array}$ & $11.1 \%$ & $10.0 \%$ & $43.3 \%$ \\
\hline $\begin{array}{l}\text { Very much like me } \\
\text { Like me }\end{array}$ & $24.4 \%$ & $24.3 \%$ & $26.7 \%$ \\
\hline Somewhat like me & $29.8 \%$ & $30.0 \%$ & $23.3 \%$ \\
\hline A little like me & $19.4 \%$ & $19.9 \%$ & $6.7 \%$ \\
\hline Not like me & $9.7 \%$ & $10.0 \%$ & - \\
\hline Not at all like me & $4.0 \%$ & $4.1 \%$ & - \\
\hline $\begin{array}{l}\text { Don't know } \\
\text { (N) Not a religious person }\end{array}$ & $1.6 \%$ & $1.7 \%$ & - \\
\hline
\end{tabular}

Source: WVS, 2018

Table 10. Significance of tradition when respondent = "an atheist"

\begin{tabular}{l|r|r|r|}
\hline & & \multicolumn{3}{|c|}{$\begin{array}{c}\text { Country Code [Relligious } \\
\text { person=An atheist] }\end{array}$} \\
\cline { 3 - 4 } & TOTAL & Estonia & Georgia \\
\hline $\begin{array}{l}\text { Schwartz: Tradition is important to this person; to follow the customs handed down } \\
\text { by one's religion or family }\end{array}$ & $5.8 \%$ & $5.0 \%$ & $33.3 \%$ \\
\hline $\begin{array}{l}\text { Very much like me } \\
\text { Like me }\end{array}$ & $15.6 \%$ & $16.0 \%$ & - \\
\hline Somewhat like me & $26.9 \%$ & $25.9 \%$ & $66.7 \%$ \\
\hline A little like me & $27.1 \%$ & $27.8 \%$ & - \\
\hline Not like me & $15.8 \%$ & $16.2 \%$ & - \\
\hline Not at all like me & $7.2 \%$ & $7.4 \%$ & - \\
\hline Don't know & $1.6 \%$ & $1.7 \%$ & - \\
(N) An atheist & 117 & 114 & 3 \\
\hline
\end{tabular}

Source: WVS, 2018 


\subsection{Trust in institutions}

When it comes to trust in institutions, the Estonian society again shows to be more trusting than Georgian, with the exception of the trust in churches. The tables below present the results of the Georgian and Estonian respondents' trust in the government and trust in religious institutions.

Table 11. Trust in churches

\begin{tabular}{|l|r|r|r|}
\hline & & \multicolumn{2}{|c|}{ Country Code } \\
\cline { 3 - 4 } & TOTAL & Estonia & Georgia \\
\hline A great deal & $36.9 \%$ & $15.7 \%$ & $64.0 \%$ \\
\hline Quite a lot & $34.2 \%$ & $42.8 \%$ & $23.1 \%$ \\
\hline Not very much & $15.9 \%$ & $22.5 \%$ & $7.4 \%$ \\
\hline None at all & $7.9 \%$ & $10.5 \%$ & $4.7 \%$ \\
\hline No answer & $0.2 \%$ & $0.3 \%$ & $0.1 \%$ \\
\hline Don't know & $5.0 \%$ & $8.3 \%$ & $0.7 \%$ \\
\hline (N) & $(2,735)$ & $(1,533)$ & $(1,202)$ \\
\hline Selected samples: Estonia 2011, Georgia 2014 & & \\
\hline
\end{tabular}

Source: WVS, 2018

Table 12. Trust in government

\begin{tabular}{|c|c|c|c|}
\hline & \multirow[b]{2}{*}{ TOTAL } & \multicolumn{2}{|c|}{ Country Code } \\
\hline & & Estonia & Georgia \\
\hline A great deal & $5.7 \%$ & $7.1 \%$ & $4.0 \%$ \\
\hline Quite a lot & $38.1 \%$ & $45.7 \%$ & $28.5 \%$ \\
\hline Not very much & $36.0 \%$ & $32.5 \%$ & $40.5 \%$ \\
\hline None at all & $17.4 \%$ & $13.3 \%$ & $22.6 \%$ \\
\hline No answer & $0.3 \%$ & $0.1 \%$ & $0.5 \%$ \\
\hline Don't know & $2.4 \%$ & $1.3 \%$ & $3.9 \%$ \\
\hline$(\mathrm{N})$ & $(2,735)$ & $(1,533)$ & $(1,202)$ \\
\hline
\end{tabular}

Selected samples: Estonia 2011,Georgia 2014

Source: WVS, 2018

The significance of the church in the Georgian society is evident from Table 11 above. Although a profound trust in religious institutions may not necessarily be considered an impediment to a country's economic development, the combination of the freedom of the priests allowed by the theological foundation of Eastern Orthodoxy with the values many of these priests promote to the adherents makes it a worrying sign. When it comes to Estonia, considering the minimal role of religion in the country, the figures from the Table above reveal that a surprisingly large number of the population to nevertheless trust 
the churches. However, when these figures are compared to people's trust in state institutions, a general tendency to trust institutions in Estonia is revealed. In Georgia, on the other hand, the trust in other institutions remains significantly low, while the trust in churches remains high. Perhaps the difference between the trust in churches in comparison to other institutions in Georgia may partly explain the reason why religiosity has a different impact on Georgia and Estonia in the various values examined in this chapter.

\section{Table 13. Trust in Parliament}

\begin{tabular}{|l|r|r|r|}
\hline & & \multicolumn{2}{|c|}{ Country Code } \\
\cline { 3 - 4 } & TOTAL & Estonia & Georgia \\
\hline A great deal & $3.2 \%$ & $3.4 \%$ & $2.8 \%$ \\
\hline Quite a lot & $32.6 \%$ & $37.5 \%$ & $26.5 \%$ \\
\hline Not very much & $39.6 \%$ & $37.7 \%$ & $42.0 \%$ \\
\hline None at all & $21.0 \%$ & $18.7 \%$ & $23.9 \%$ \\
\hline No answer & $0.2 \%$ & $0.2 \%$ & $0.3 \%$ \\
\hline Don't know & $3.4 \%$ & $2.5 \%$ & $4.5 \%$ \\
\hline (N) & $(2,735)$ & $(1,533)$ & $(1,202)$ \\
\hline Selected samples: Estonia 2011, Georgia 2014 & & \\
\hline
\end{tabular}

Source: WVS, 2018

\section{Conclusion}

Overall, the findings of this research suggest that the secularization theory is wrong in assuming that the impact of religion has disappeared from the public sphere. Although religion no longer plays an active role in Estonia today, its influence is still significant in the theoretically secular Georgia. Hence, religion must be considered and studied as a dynamic, active factor in development rather than considering it as a mere component of a country's history and politics. Such analysis will allow for a clearer understanding of the constraints to a country's development and consequently prompt more effective development policies to form in the country.

This article introduced merely one method of studying religion in economic development - by incorporating it into contemporary development studies. For further research, the reason why Georgian religiosity impedes the development of certain values in the country can be investigated more closely. For instance, research can be done on Eastern Orthodoxy as a whole, or perhaps on the post- 
Soviet Eastern Orthodox nations, to find whether they follow a common pattern in development, or if Eastern Orthodoxy impacts each country differently. Furthermore, the European Value Survey and the Caucasus Barometer can be incorporated with the WVS for better and more credible results.

Anastasia Mgaloblishvili graduated with honors from Tallinn University of Technology's International Relations program in 2018. With a passion for development studies, she wrote her bachelor's thesis on the role of religion in the post-Soviet economic development of Georgia and Estonia. She is currently pursuing an internship in the German Marshall Fund's Warsaw office and will continue her master's studies in the London School of Economics' International Political Economy program from September 2019. Her previous work experience includes interning in Estonia's International Center for Defense and Security and serving as a student ambassador for TalTech.

\section{References}

Åslund, A. (2012), How Capitalism was Built, 2nd ed., New York: Cambridge University Press. https://doi.org/10.1017/CBO9780511790416

Bulgakov, S. (1909), 'The national economy and the religious personality,' Journal of Markets and Morality, vol. 11(2008), no. 1, pp. 157-179.

Chikovani, N. (2012), 'The Georgian historical narrative: From pre-Soviet to postSoviet nationalism,' Dynamics of Asymmetric Conflict, vol. 5, no. 2, pp. 107-115. https://doi.org/10.1080/17467586.2012.742953

Chochia, A. \& Popjanevski, J. (2016), 'Change of power and its influence on country's Europeanization process. Case Study: Georgia,' in T. Kerikmäe \& A. Chochia (eds.) Political and Legal Perspectives of the EU Eastern Partnership Policy, Cham: Springer International Publishing, pp. 197-210.

https://doi.org/10.1007/978-3-319-27383-9_13

Grdzelidze, T. (2010), 'The Orthodox Church of Georgia: challenges under democracy and freedom,' International Journal for the Study of the Christian Church, vol. 10, nos. 2-3, pp. 160-175. https://doi.org/10.1080/1474225X.2010.487719

Gurchiani, K. (2017), 'How Soviet is the religious revival in Georgia: tactics in everyday religiosity,' Europe-Asia Studies, vol. 69, no. 3, pp. 508-531. https://doi.org/10.1080/09668136.2017.1323324

Hoffmann, T. \& Chochia, A. (2018), 'The institution of citizenship and practices of passportization in Russia's European Neighborhood Policies,' in A. Makarychev \& T. Hoffmann (eds.) Russia and the EU Spaces of Interaction, Abingdon: Routledge, Taylor \& Francis Group, pp. 223-237. 
Huntington, S. P. (1996), 'The West: unique, not universal,' Foreign Affairs, vol. 75, no. 6, pp. 28-46. https://doi.org/10.2307/20047828

Kerikmäe, T. (2009), Estonia in the European Legal System: Protection of the Rule of Law through Constitutional Dialogue, Tallinn: Tallinn University.

Kerikmäe, T.; Nyman-Metcalf, K.; Gabelaia, D. \& Chochia, A (2014), 'Cooperation of post-Soviets with the aim of not being "post" and "Soviets",' in N. Šišková (ed.) From Eastern Partnership to the Association. The Legal and Political Analysis, Newcastle upon Tyne: Cambridge Scholars Publishing, pp. 144-159.

Kuldkepp, M. (2013), 'The Scandinavian connection in early Estonian nationalism,' Journal of Baltic Studies, vol. 44, no. 3, pp. 313-338.

https://doi.org/10.1080/01629778.2012.744911

Kupatadze, A. (2016), 'Georgia's break with the past,' Journal of Democracy, vol. 27, no. 1, pp. 110-123. https://doi.org/10.1353/jod.2016.0003

Made, V. (2003), 'Estonia and Europe: A common identity or an identity crisis?' in M. Lehti \& D. J. Smith (eds.) Post-Cold War Identity Politics: Northern and Baltic Experience, London: Frank Cass, pp. 181-195.

Metreveli, T. (2016), 'An undisclosed story of roses: church, state, and nation in contemporary Georgia,' The Journal of Nationalism and Ethnicity, vol. 44, no. 5, pp. 694-712.

Papava, V. (2009), 'Georgia's economy: post-revolutionary development and postwar difficulties,' Central Asian Survey, vol. 28, no. 2, pp. 199-213. https://doi. org/10.1080/02634930903043717

Pigenko, V. \& Novac, C. (2002), 'Economic reforms and ethnic nationalism in the context of transition to democracy: the case of four Eastern European nations,' Democratization, vol. 9, no. 4, pp. 159-172.

https://doi.org/10.1080/714000285

Ringvee, R. (2001), 'Religious freedom and legislation in Post-Soviet Estonia,' BYU Law Review, vol. 2001, no. 2, art. 11.

Sutidze, L. (2015), 'Conversation on religion: Nutsa Batiashvili - nationalism and

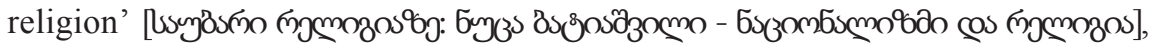
[Television programme] Tabula TV, 30 April. Retrieved from https://www. youtube.com/watch? $=\mathrm{vd} 22 \mathrm{kWvNxAE}$ [accessed 11 April 2018]

Sutidze, L. (2016), 'Conversation on religion: The sociology of religion-Emzar

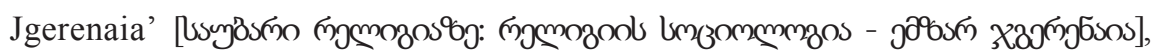
[Television programme] Tabula TV, 27 October. Retrieved from https://www. youtube.com/watch?v=tz5NuFrVXng [accessed 11 April 2018]

The World Bank (2018), Worldwide Governance Indicators. Retrieved from http://info. worldbank.org/governance/wgi/\#home [accessed 9 May 2018]

The World Bank Databank (2018), 'The World Bank International Comparison Program database' [Custom cross-tabulation of data]. Retrieved from https://data. 
worldbank.org/indicator/NY.GDP.PCAP.PP.CD?locations=GE-EE [accessed 9 May 2018]

Todaro, P. M. \& Smith, C. S. (2010), Economic Development, 11 th ed. Boston: Pearson. WVS (2018), 'Online data analysis' [Custom cross-tabulation of data], World Value Survey. Retrieved from http://www.worldvaluessurvey.org/WVSOnline.jsp [accessed 7 May 2018]

Weber, M.; Gerth, H. H. \& Mills, C. W. (1982[1948]), From Max Weber: Essays in Sociology, London: Routledge.

Wheatley, J. (2009), 'Managing ethnic diversity in Georgia: one step forwards, two steps back,' Central Asian Survey, vol. 28, no. 2, pp. 119-134.

https://doi.org/10.1080/02634930903034880 